\title{
A CASE REPORT OF RARE INTRAPARENCHYMAL LEIOMYOMA OF THE BREAST - DIAGNOSTIC AND HISTOPATHOLOGICAL FEATURES
}

\author{
DOMAGOJ ELJUGA ${ }^{1}$, ANA MARIJA POPOVIĆ ${ }^{1}$, \\ MIRTA ZEKAN VUČETIĆ ${ }^{2}$ and MARIJA MILKOVIĆ PERIŠA ${ }^{3}$ \\ ${ }^{1}$ Department of Oncoplastic and Reconstructive Surgery, University Hospital for Tumors, \\ Sestre Milosrdnice University Hospital Center, Zagreb, Croatia; \\ ${ }^{2}$ Division of Diagnostic and Interventional Radiology, department of Oncological Radiology, \\ University Hospital for Tumors, Sestre Milosrdnice University Hospital Center, Zagreb, Croatia; \\ 32Department of Oncological Pathology, 'Ljudevit Jurak' University Department of Pathology, \\ University Hospital for Tumors, Sestre Milosrdnice University Hospital Center, Zagreb, Croatia
}

\begin{abstract}
Summary
Leiomyomas are one of the rarest neoplasms of the breast. Intraparenchymal leiomyomas can present a diagnostic challenge, as they can resemble other benign, and more importantly, malignant lesions - especially leiomyosarcomas. Here we report a case of a 28-year old female patient with a palpable mass in the right upper quadrant of the right breast and present diagnostic and histopathological features, with special reference to magnetic resonance imaging.
\end{abstract}

KEYWORDS: breast neoplasms, leiomyoma, smooth muscle tumor, magnetic resonance imaging, differential diagnosis

\section{PRIKAZ SLUČAJA RIJETKOG UNUTARPARENHIMNOG LEIOMIOMA DOJKE - DIJAGNOSTIČKE I PATOHISTOLOŠKE ZNAČAJKE}

\section{Sažetak}

Leiomiomi su izrazito rijetki tumori dojke. Unutarparenhimni leiomiomi predstavljaju dijagnostički izazov, jer mogu nalikovati na druge dobroćudne i zloćudne tvorevine, posebice na leiomiosarkom. U radu je prikazan slučaj 28-godišnje žene s opipljivom masom u desnoj gornjoj četvrtini desne dojke. Opisane su dijagnostičke i patohistološke značajke nađenog tumora, s posebnim osvrtom na magnetsku rezonanciju.

KLJUČNE RIJEČI: tumori dojke, leiomiom, tumor glatkih mišića, magnetska rezonancija, diferencijalna dijagnoza

\section{INTRODUCTION}

Leiomyoma is a smooth muscle tumor, frequently found in the gastrointestinal and female reproductive organs, especially uterus (1). Due to its origin, leiomyoma is one of the rarest neoplasms of the breast. There are currently two subgroups - more frequent, superficial or subareolar leiomyomas, and more infrequent, intraparenchy- mal leiomyomas (2). We will report a rare case of breast intraparenchymal leiomyoma along with diagnostic and histopathologic features.

\section{CASE REPORT}

A 28-year old female patient with a palpable mass in her right breast presented in our surgical 


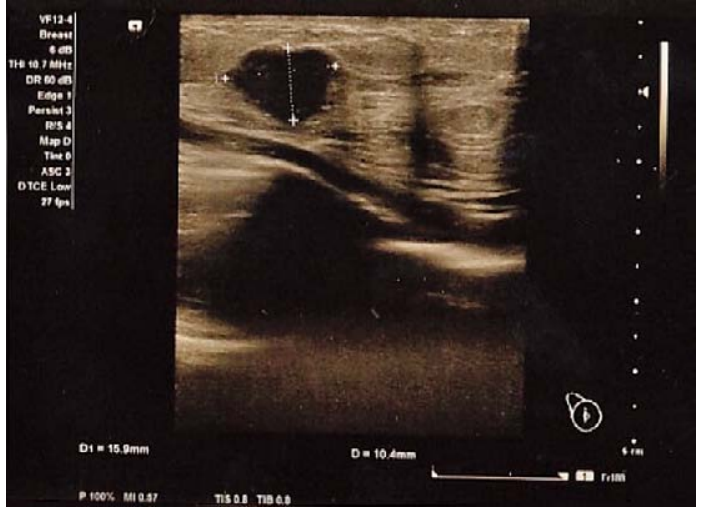

Figure 1. Breast ultrasonography shows a $1,5 \mathrm{~cm}$ sized hypoechoic lesion with circumscribed margins.

outpatient clinic. On physical examination, the firm lesion was on the border of the upper quadrants of the right breast. The diameter of the lesion was around $2 \mathrm{~cm}$, and the distance from the nipple was $7 \mathrm{~cm}$. Axillary lymph nodes were not enlarged. Despite the positive history of familial breast cancer (both grandmothers at the age of 60), this was her first visit to a physician for a breast check-up.

Ultrasonography (US) of the right breast showed a 1,5 cm sized, circumscribed, oval, hypoechoic structure (Fig.1). There was a suspicious dense cyst on the initial examination, but given the age of the patient and her positive family history of breast cancer, the cytological examination was performed. The result of fine-needle aspiration (FNA) was consistent with a mesenchymal tumor. After that, the patient was referred for a magnetic resonance (MR) imaging of the breast. The breast magnetic resonance imaging (MRI) showed the mass on the border of the upper quadrants of the right breast, measuring $2.2 \mathrm{~cm}$ in the longest diameter. The mass was isointense with surrounding tissue on pre-contrast T1-weighted sequences (Fig. 2a), and it was of the high intensity on short tau inversion recovery (STIR) sequence (Fig. 2b).

At subtraction sequences, the mass showed intense postcontrast enhancement, somewhat heterogeneous in the middle, but with progressive enhancement pattern, which in most cases indicates benign mass on MRI scans (Fig. 2c). Therefore, the MRI, in this case, was not conclusive of benignity. There were no other signs of postcontrast enhancement in both breasts on the MRI scan. The mass was assessed as breast imaging reporting and data system (BIRADS) 4 category. The lymph nodes in both axillary regions were described as reactive, benign lymph nodes, both on US and MR examinations.

We referred the patient to open surgical biopsy to confirm the diagnosis. The tumor with around $1 \mathrm{~cm}$ of the surrounding tissue was resected.

Histopathological analysis of the specimen revealed a well-circumscribed, rubbery white tumor with a white whorled cut surface, in the middle of the resected breast tissue. The diameter of the tumor was $1.7 \mathrm{~cm}$, with free resection margins. Histologically, it consisted of interlacing fascicles of spindle-shaped cells with oval nuclei without mitotic figures, cell atypia or necrosis (Fig. 3a). Immunohistochemical analysis showed strong dif-

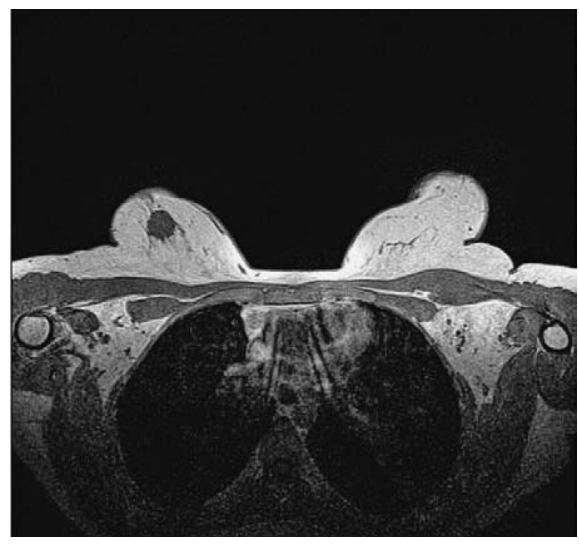

Figure 2a. The T1-weighted axial MRI shows an isointense lesion.

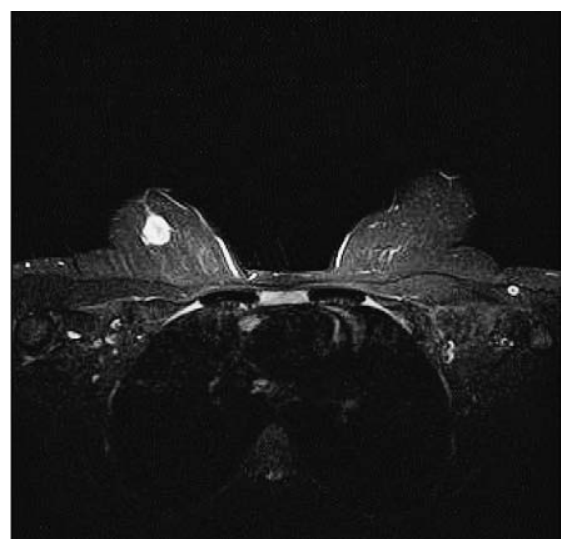

Figure $2 b$. The lesion was of high intensity on STIR sequence.

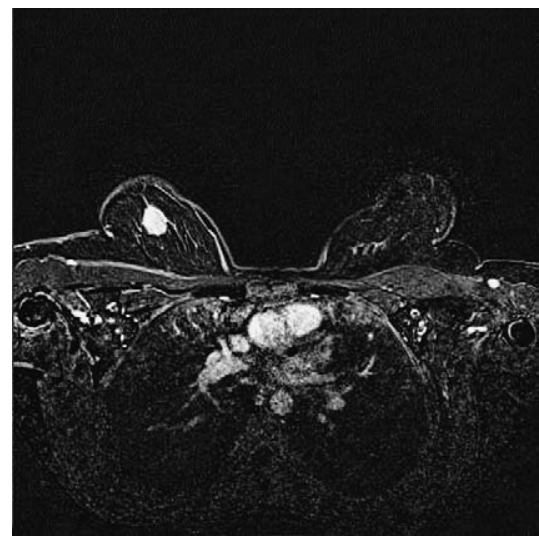

Figure 2c. On subtraction sequences the lesion shows intense postcontrast enhancement. 


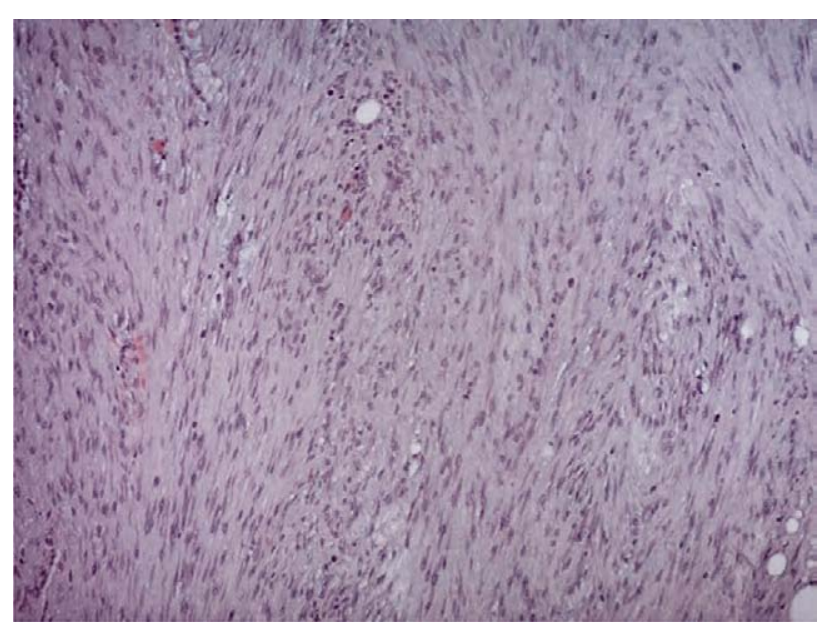

Figure 3a. Histopathologic analysis of the specimen shows interlacing fascicles of spindle-shaped cells with oval nuclei. Magnification $50 x$.

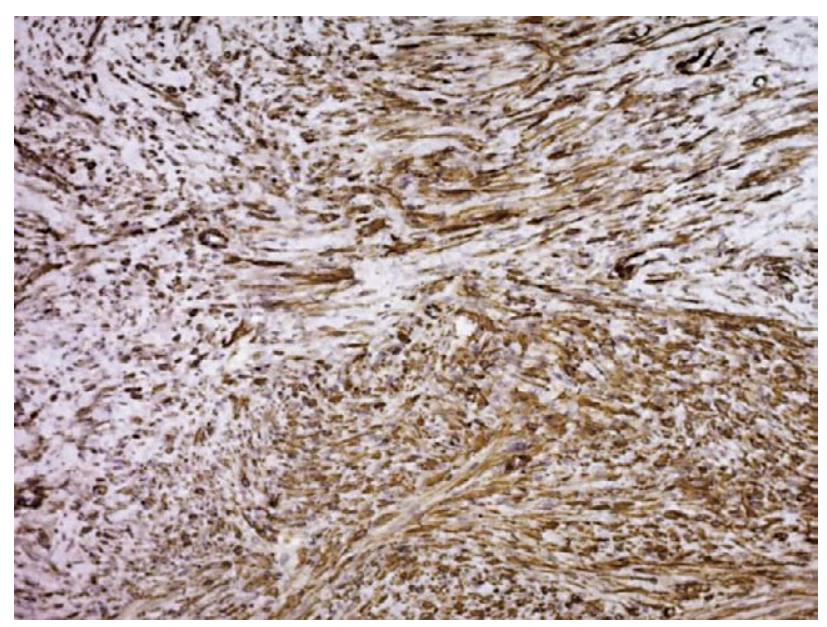

Figure 3b. Immunohistochemical analysis shows diffuse positivity for smooth-muscle actin (Dako, Clone 1A4). Magnification $50 x$.

fuse positivity for smooth-muscle actin (Dako, Clone 1A4) and strong focal positivity for desmin (Dako, Clone D33) (Fig. 3b). According to histology and immunohistochemical results, the tumor was a leiomyoma of the breast.

\section{DISCUSSION}

Leiomyomas are benign non-epithelial tumors, described as benign spindle cell lesions, nonspecific to mammary stroma (3). While subareolar leiomyomas are a common finding in both sexes, intraparenchymal type of leiomyomas rare- ly occurs middle-aged women (4). They were described in approximately 30 cases so far, with only one case in men (5). Although there are various theories, the etiology of deep parenchymal leiomyomas is still undetermined. It is most likely that smooth muscle cells, which form the tumor, originate from the walls of mammary blood vessels. Alternatively, smooth muscle lesions in the breast could form from the teratoid origin, from a multipotent mesenchymal cell, angiomatous smooth muscle, or myoepithelial cells of breast ducts (6).

Clinically, intraparenchymal leiomyomas of the breast appear as painless, firm, and mobile nodules, with well-defined borders and variable size (7). Their slow growth is consistent with their benign nature.

The diagnostic approach mostly includes mammography, sonography, needle-core biopsy, and, as in our case, magnetic resonance imaging. Leiomyomas usually appear as well-circumscribed lesions on mammography and ultrasonography. On mammography, the lesion is either isodense or hyperdense with no radial extensions, and no microcalcification $(6,8)$. Sonographic criteria are nonspecific and include hypoechoic lesion with or without decreased posterior acoustic shadowing $(9,10)$. Minami et al reported the first case of intraparenchymal leiomyoma evaluated by MRI. They noticed that these lesions can be divided into degenerative and nondegenerative forms using MRI, but that the MRI is inconclusive in terms of distinguishing between malignant and benign entities and/or type of degeneration (11). Our findings on MR scans correspond to features of leiomyomas arising elsewhere in the body.

The benign breast lesions remain underrecognized, which makes it even more essential to differentiate them from more aggressive and malignant entities (3). Since leiomyomas show similar clinical and radiologic features as other benign and/or malignant diseases of the breast, a thorough histological and immunohistochemical analysis should be administered (12). Differential diagnosis of intraparenchymal leiomyoma includes numerous other lesions: myofibroblastoma, fibromatosis, phyllodes tumors, benign spindle cell tumor, spindle cell myoepithelioma, fibroadenoma, adenomyoepithelioma. Nevertheless, differentiating leiomyoma from leiomyosarcoma is of great importance $(2,4,13)$. Leiomyosarcoma is a malignant 
smooth muscle tumor with a predisposition for local recurrence and distal spreading and represents a diagnostic challenge in the evaluation of smooth muscle tumors (14). Histopathological analysis of suspected lesion is the only way to differentiate leiomyomas and leiomyosarcomas. The absence of cell atypia, mitosis, vascular invasion, and necrosis favors the benign nature of the lesion (14).

The treatment of choice for intraparenchymal leiomyomas is excision with free margins. Contrary to leiomyosarcoma, no tendency for local recurrence or distal spreading is seen (9).

\section{CONCLUSION}

Intraparenchymal leiomyomas are one of the rarest described neoplasms of the breast. The lack of specific radiologic features and a wide range of differential diagnoses, which include not only benign breast lesions but, more importantly, aggressive and malignant entities, makes it difficult to establish an accurate diagnosis. The only definite diagnostic method is the histological evaluation of the lesion. The presented case is the second reported case of leiomyoma of the breast recognized on MRI. In our opinion, MRI is of great value for the diagnosis and evaluation of benign breast lesions, as it can detect and characterize small lesions and provide essential information for adequate treatment and follow-up.

\section{Acknowledgments}

All authors declare that they have no conflict of interest.

\section{REFERENCES}

1. Sampaio GP, Koch MV, Boechat M, Matos VE, dos Santos AASMD. Leiomyoma of the breast: an uncommon tumor. Radiol Bras. 2016;49(5):343-4.

2. Kafadar MT, Yalcin M, Gok MA, Aktas A, Yurekli TS, Arslan AI. Intraparenchymal leiomyoma of the breast: a rare location for an infrequent tumor. Eur J Breast Health. 2017;13(3):156-8.
3. Magro G. Differential diagnosis of benign spindle cell lesions. Surg Pathol Clin. 2018;11(1):91-121.

4. Sidoni A, Lüthy L, Bellezza G, Consiglio MA, Bucciarelli E. Leiomyoma of the breast: case report and review of the literature. The Breast. 1999;8:289-90.

5. Strader LA, Galan K, Tenofsky PL. Intraparenchymal leiomyoma of the male breast. Breast J. 2013;19(6): 675-6.

6. Heyer H, Ohlinger R, Schimming A, Schwesinger G, Grunwald S. Parenchymal leiomyoma of the breast-clinical, sonographic, mammographic and histological features. Ultraschall Med. 2006;27(1):55-8.

7. Kaufman HL, Hirsch E. Leiomyoma of the breast. J Surg Oncol. 1996;62:62-4.

8. Brandao RG, Elias S, Pinto Nazario AC, Alcoforado Assuncao M, Esposito Papa CC, Facina G. Leiomyoma of the breast parenchyma: a case report and review of the literature. Sao Paulo Med J. 2018;136(2):177-81.

9. Granic M, Stefanovic-Radovic M, Zdravkovic D, Ivanovic N, Nikolic D, Radovanovic D, Stojiljkovic M. Intraparenchimal leiomyoma of the breast. Arch Iran Med.18(9):608-12.

10. Cho HJ, Kim SH, Kang BJ, Kim H, Song BJ, Lee AW. Leiomyoma of the nipple diagnosed by MRI. Acta Radiol Short Rep. 2012;1:28. DOI: 10.1258/arsr.2012.120025.

11. Minami S, Matsuo S, Azuma T, Uga T, Hayashi T, Eguchi S, et al. Parenchymal leiomyoma of the breast: a case report with special reference to magnetic resonance imaging findings and an update review of literature. Breast Cancer. 2011;18(3):231-6.

12. Ende L, Mercado C, Axelrod D, Darvishian F, Levine $\mathrm{P}$, Cangiarella J. Intraparenchymal leiomyoma of the breast: a case report and review of the literature. Ann Clin Lab Sci. 2007;37(3):268-73.

13. Abd el-All HS. Breast spindle cell tumours: about eight cases. Diagn Pathol. 2006;1:13.

14. Pourbagher A, Pourbagher MA, Bal N, Oguzkurt L, Ezer A. Leiomyoma of the breast parenchyma. AJR Am J Roentgenol. 2005;185(6):1595-7.

Corresponding author: Domagoj Eljuga, Department of Oncoplastic and Reconstructive Surgery, University Hospital for Tumors, Sestre Milosrdnice University Hospital Center, Ilica 197, 10000 Zagreb, Croatia. e-mail: deljuga@gmail.com 